\title{
Oxidation of AISI 304L and 348 Stainless Steels in Water at High Temperatures
}

\author{
Alan Matias Avelar ${ }^{a}$ * (D), Claudia Giovedi ${ }^{b}$, Alfredo Yuuitiro Abe $^{c}$, Marcelo Breda Mourão \\ ${ }^{a}$ Universidade de São Paulo, Departamento de Engenharia Metalúrgica e de Materiais, \\ São Paulo, SP, Brasil \\ ${ }^{b}$ Universidade de São Paulo, Departamento de Engenharia Naval e Oceânica, Laboratório de Análise, \\ Avaliação e Gerenciamento de Risco, São Paulo, SP, Brasil \\ 'Instituto de Pesquisas Energéticas e Nucleares, São Paulo, SP, Brasil
}

Received: August 17, 2020; Accepted: October 31, 2020

Oxidation of AISI $304 \mathrm{~L}$ and 348 stainless steels was investigated in water at $1000-1350{ }^{\circ} \mathrm{C}$ by TGA, SEM, EDS, and Raman spectroscopy. Linear-Parabolic kinetics and multilayer oxide scales with voids were found for both alloys. Based on the experimental results, AISI 304L presented higher oxidation resistance and higher activation energy. Zircaloy-4 kinetic results were used for validation and performance comparison. In severe accidents conditions, stainless steel might lead to a faster hydrogen production comparing to Zircaloy.

Keywords: Stainless steel, Oxidation, Hydrogen, AISI 348, AISI 304L.

\section{Introduction}

The nuclear industry with universities and research institutes are making great efforts to improve the safety in nuclear reactors by developing Accident Tolerant Fuels $(\mathrm{ATF})^{1-3}$. Although austenitic steel clad operated reliably in Pressurized Water Reactors (PWR), its thermal neutron absorption cross section is a factor of 12-16 times higher than Zircaloy. Therefore, the fuel enrichment penalty incurred by the use of Stainless Steel (SS) cladding became the primary driver for the replacement of stainless steel cladding by Zircaloy cladding in commercial reactors ${ }^{1,3}$. Nowadays, zirconium based alloys enjoy a monopoly for uranium oxide fuel cladding material in Light Water Reactors (LWR). However, the continuous interest on nuclear safety improvement in Nuclear Power Plants (NPP) demands the evaluation the of low-probability events consequences, called Severe Accidents (SA), such as Three Mile Island in 1979 and more recently, Fukushima Daiichi in 2011 2-5.

During severe accidents, core cooling might be interrupted. The decay heat and metal-water reaction enthalpy drive the core temperature upward. As the water level decreases and core becomes uncovered, the heat transfer processes become less efficient and the fuel assemblies start to experience physical and chemical degradation, or even melting. Physical degradation occurs first $\left(700-1000^{\circ} \mathrm{C}\right)$ and involves swelling (ballooning) and burst of the thin-walled fuel rod cladding tube. Chemical degradation occurs on higher temperatures (mainly above $1000{ }^{\circ} \mathrm{C}$, depending on the cladding material) and it is dominated by water oxidation reaction, which is highly exothermic ${ }^{6-8}$.

Once the cladding temperature reaches values above $1204{ }^{\circ} \mathrm{C}$, US-NRC (Nuclear Regulatory Commission) specified Peak Cladding Temperature (PCT) under design

*e-mail: alan.matias@marinha.mil.br basis Loss-of-Coolant Accidents (LOCA) ${ }^{9}$, the temperature rises rapidly in the fuel. This rapid increase is due to the very high oxidation rate of zirconium based alloys above $1200{ }^{\circ} \mathrm{C}$ in water ${ }^{3}$.

Despite presenting the advantage of neutron economy, zirconium-water reaction generates substantially more energy $(-1560 \mathrm{kcal} / \mathrm{kg}$ ) than stainless steel (from -144 up to $-253 \mathrm{kcal} / \mathrm{kg})^{6,10}$. Due to stainless steel higher oxidation resistance, especially at temperature range that could possibly take place in Design-Basis Accidents (DBA), it may present safety advantages ${ }^{11}$. As the melting point of stainless steel is approached at $1370-1500^{\circ} \mathrm{C}$, its oxidation rate can become much higher comparing to zirconium based alloys ${ }^{10}$. However, prolonged core uncovery would probably be required to achieve these temperatures.

Many authors have studied the oxidation of stainless steel under high temperature conditions ${ }^{12-17}$. However, few works have been carried out at temperatures above $1200^{\circ} \mathrm{C}$ and in water. The $304 \mathrm{SS}$ appears as the most commonly studied alloy in the literature ${ }^{11,15-17}$. When these alloys are exposed at high temperatures, an initial fast period of reaction is followed by a reduction in reaction rate due to the development of a corrosion resistant scale. Considering the application as cladding material, this period of rapid oxidation is important for alloy design and selection ${ }^{18}$.

It is generally observed that the presence of water significantly accelerates the oxidation rate comparing to dry air ${ }^{15,18}$. Oxidation of Fe-Cr-Ni alloys is highly dependent on $\mathrm{Cr}$ content $^{19}$. Chromium levels greater than $20 \%$ led to the formation of a protective oxide scale with the associated low diffusion rates through the scale and hence low oxidation rates, comparable with that of pure chromium ${ }^{19}$. Pint et al. ${ }^{2}$ showed that $25 \% \mathrm{Cr}$ was needed to form a protective $\mathrm{Cr}_{2} \mathrm{O}_{3}$ scale at $1200{ }^{\circ} \mathrm{C}$. Thus, both 304 and 348 SS cannot be considered as an ATF candidate. 
Table 1. Chemical composition in weight $\%$.

\begin{tabular}{cccc}
\hline $\begin{array}{c}\text { Chemical } \\
\text { Element }\end{array}$ & AISI 304L & AISI 348 & Zr-4 \\
\hline $\mathrm{Fe}$ & 71.65 & 68.63 & 0.20 \\
\hline $\mathrm{Cr}$ & 18.50 & 17.45 & 0.10 \\
\hline $\mathrm{Ni}$ & 8.30 & 10.94 & - \\
\hline $\mathrm{C}$ & 0.008 & 0.052 & 0.01 \\
\hline $\mathrm{Si}$ & 0.13 & 0.42 & - \\
\hline $\mathrm{Mn}$ & 0.90 & 1.61 & - \\
\hline $\mathrm{P}$ & 0.008 & 0.017 & - \\
\hline $\mathrm{Cu}$ & 0.36 & - & - \\
\hline $\mathrm{V}$ & 0.02 & - & - \\
\hline $\mathrm{Ta}$ & $<0.05$ & $<0.005$ & - \\
\hline $\mathrm{Co}$ & 0.05 & 0.023 & - \\
\hline $\mathrm{Nb}$ & $<0.01$ & 0.83 & - \\
\hline $\mathrm{S}$ & 0.0025 & 0.003 & - \\
\hline $\mathrm{B}$ & 0.0008 & 0.0007 & - \\
\hline $\mathrm{N}$ & 0.0055 & 0.018 & - \\
\hline $\mathrm{O}$ & - & - & 0.13 \\
\hline $\mathrm{Sn}$ & - & - & 1.36 \\
\hline $\mathrm{Zr}$ & - & - & 98.20 \\
\hline
\end{tabular}

Using stoichiometric calculations ${ }^{10,17}$, hydrogen generation curves may be derived from weight gain models. This study presents kinetic results of AISI 348 oxidation in water at high temperatures and compares its performance against other materials commonly applied in nuclear reactors. The obtained oxidation kinetics model is applicable to predict hydrogen generation in the calculation of a hypothetical LOCA in a LWR employing 348 SS cladding.

\section{Experimental}

\subsection{Sample preparation}

Samples in disc formats of AISI 304L, 348 and Zr-4 with dimensions of $22 \mathrm{~mm}$ (diameter) x $2 \mathrm{~mm}$ (thickness) were studied. Chemical compositions in weight $\%$ are given in Table 1.

\subsection{Oxidation exposures}

Flowing steam was generated by pumping approximately $1.33 \mathrm{~mL} / \mathrm{min}$ of distilled water into the heating device at $300{ }^{\circ} \mathrm{C}$. Isothermal water oxidation experiments were carried out in a Lindberg/Blue $\mathrm{M}^{\circledR}$ furnace connected to a steam generator.

During all experiments, the furnace heating rate was set as $15^{\circ} \mathrm{C} / \mathrm{min}$. When the furnace temperature achieved the desired value for the test, it remained at this temperature for at least $5 \mathrm{~h}$ before the beginning of the experiment.

The weight gain data of the Thermal Gravimetric Analysis (TGA) was obtained by a Shimadzu ${ }^{\circledR}$ analytical balance placed above the furnace. A nickel chrome wire hanged a high alumina crucible where the samples were exposed to water. Once the nitrogen flow was interrupted, the steam was introduced immediately and the oxidation exposure time started to count. All tests had the same duration of $90 \mathrm{~min}$. After oxidation, the steam flow was switch off and the samples were cooled down to room temperature.

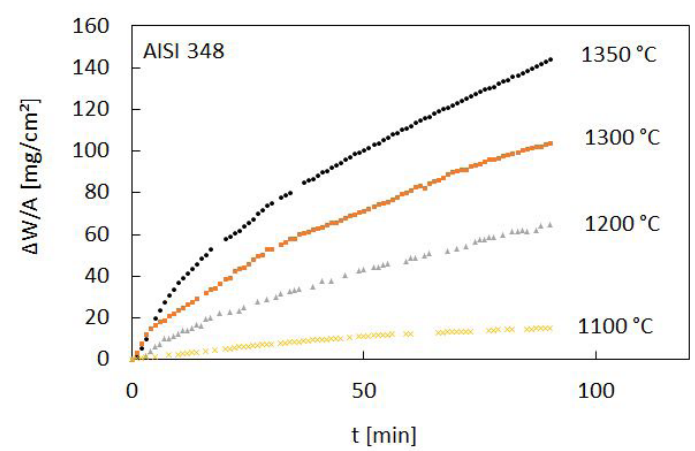

Figure 1. Evolution of the weight gain for AISI 348 at $1100{ }^{\circ} \mathrm{C}$, $1200{ }^{\circ} \mathrm{C}, 1300{ }^{\circ} \mathrm{C}$ and $1350{ }^{\circ} \mathrm{C}$ in water.

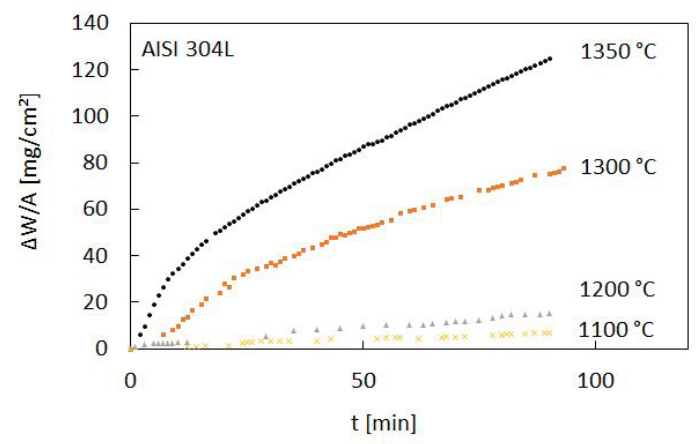

Figure 2. Evolution of the weight gain for AISI $304 \mathrm{~L}$ at $1100{ }^{\circ} \mathrm{C}$, $1200{ }^{\circ} \mathrm{C}, 1300^{\circ} \mathrm{C}$ and $1350{ }^{\circ} \mathrm{C}$ in water.

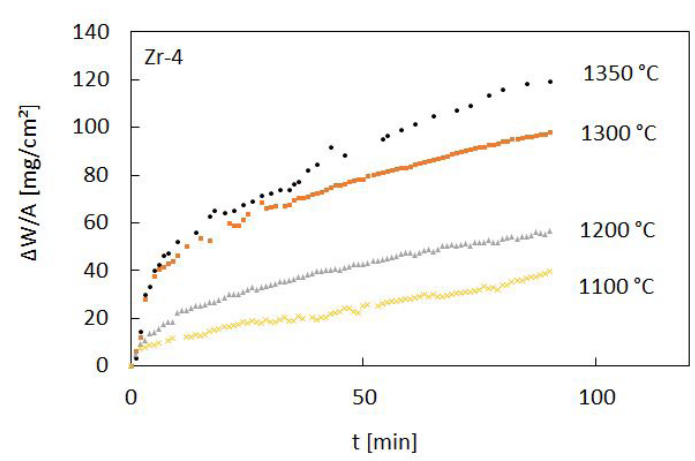

Figure 3. Evolution of the weight gain for Zircaloy-4 at $1100{ }^{\circ} \mathrm{C}$, $1200{ }^{\circ} \mathrm{C}, 1300{ }^{\circ} \mathrm{C}$ and $1350{ }^{\circ} \mathrm{C}$ in water.

\subsection{Characterization techniques}

The oxidized samples were characterized in terms of scale thickness and composition. Scales were investigated by Scanning Electron Microscopy (SEM). Oxide layers were analyzed by Energy Dispersive Spectroscopy (EDS) and Raman spectroscopy. The outmost surfaces were also analyzed by EDS.

\section{Results and Discussion}

\subsection{Oxidation kinetics}

The oxidation kinetics results are shown in Figures 1,2 and 3. Figure 1 shows that AISI 348 presented significant weight 
Table 2. Kinetic parameters of 304 SS models and the proposed model for AISI 348.

\begin{tabular}{|c|c|c|c|c|}
\hline Material / & AISI 348 & 304L SS & $304 \mathrm{SS}$ & $304 \mathrm{SS}$ \\
\hline Kinetic Parameter & This study & Brassfield et al. $(1968)^{7,15}$ & Ishida et al. ${ }^{7,16}$ & Ishida et al. ${ }^{7,16}$ \\
\hline & $1000^{\circ} \mathrm{C} \leq \mathrm{T} \leq 1350^{\circ} \mathrm{C}$ & $1000^{\circ} \mathrm{C} \leq \mathrm{T} \leq 1375^{\circ} \mathrm{C}$ & $900^{\circ} \mathrm{C} \leq \mathrm{T} \leq 1200^{\circ} \mathrm{C}$ & $1200^{\circ} \mathrm{C}<\mathrm{T} \leq 1350^{\circ} \mathrm{C}$ \\
\hline $\mathrm{A}_{0}\left(\mathrm{~kg}^{2} / \mathrm{m}^{4} / \mathrm{s}\right)$ & $4.85 \times 10^{7}$ & $2.40 \times 10^{8}$ & $7.34 \times 10^{3}$ & $1.85 \times 10^{11}$ \\
\hline $\mathrm{E}_{\mathrm{A}}(\mathrm{kJ} / \mathrm{mol})$ & $333-354$ & $343-363$ & $240-277$ & $442-498$ \\
\hline
\end{tabular}

Table 3. Kinetic parameters of Zircaloy models.

\begin{tabular}{cccc}
\hline $\begin{array}{c}\text { Material } / \\
\text { Kinetic Parameter }\end{array}$ & Zr-4 & Cathcart-Pawel $(\mathrm{CP})^{21,23}$ & Baker-Just $\left.^{(\mathrm{BJ})}\right)^{20}$ \\
\cline { 2 - 4 } $\mathrm{A}_{0}\left(\mathrm{~kg}^{2} / \mathrm{m}^{4} / \mathrm{s}\right)$ & This study & 36.22 & 409.97 \\
\hline $\mathrm{E}_{\mathrm{A}}(\mathrm{kJ} / \mathrm{mol})$ & 119 & 167 & 190 \\
\hline
\end{tabular}

gain at $1200{ }^{\circ} \mathrm{C}$, whereas Figure 2 shows that AISI 304L presented higher oxidation resistance comparing to AISI 348 at the same temperature. On the other hand, Figure 3 shows that Zircaloy-4 already presented significant oxidation at $1100{ }^{\circ} \mathrm{C}$.

Both SS followed a linear rate law in the in the first 10-30 minutes. After this early linear stage, the oxidation kinetics gradually changed to parabolic. The parabolic scaling kinetics provides indications that local equilibrium was achieved at the scale/gas interface and solid diffusion process tended to be the rate-controlling step.

The data obtained in the experiments with AISI 348 oxidation yielded the parabolic model given by Equation 1 .

$$
\left(\frac{\Delta \mathrm{w}}{\mathrm{A}}\right)^{2}=4.85 \cdot 10^{7} \cdot \exp \left(\frac{-41338 \pm 1257}{\mathrm{~T}}\right) \cdot \mathrm{t}
$$

Where $\Delta \mathrm{w} / \mathrm{A}$ is mass-gain per unit area $\left(\mathrm{kg} / \mathrm{m}^{2}\right), \mathrm{t}$ is time (s), and $\mathrm{T}$ is temperature $(\mathrm{K})$. For a better fit in the initials 30 minutes, the linear model given by Equation 2 should be used.

$\left(\frac{\Delta \mathrm{w}}{\mathrm{A}}\right)=1.13 \cdot 10^{3} \cdot \exp \left(\frac{-23247}{\mathrm{~T}}\right) \cdot \mathrm{t}$

Kinetic models are available in the literature for 304 SS oxidation in water ${ }^{10,15-17}$. The results for AISI 304L are in accordance with those obtained by Ishida et al. ${ }^{16}$, where two parabolic equations were proposed to describe the oxidation.

The metal-water kinetics of Zircaloy has been investigated by many authors ${ }^{10,17,20-23}$. The results for $\mathrm{Zr}-4$ are in accordance with those obtained by Baker-Just (BJ) ${ }^{20}$ and Cathcart-Pawel $(\mathrm{CP})^{21,23}$. The slightly higher activation energy and parabolic constants might be due to the higher enthalpy of reaction that could have increased locally $\mathrm{Zr}-4$ temperature accelerating reaction kinetics. Nevertheless, a very similar correlation was found.

The aim of the experiments conducted with 304 SS and Zircaloy was to compare against literature correlations in order to validate the experimental methodology. Tables 2 and 3 compare the kinetic parameters of SS models and Zircaloy models, respectively.

The Arrhenius plot presented in Figure 4 shows that AISI 348 and AISI 304L both have higher activation energy comparing to Zircaloy-4. Figure 5 shows another Arrhenius plot with the proposed model for AISI 348 and its confidence intervals, considering a confidence level of $90 \%$,

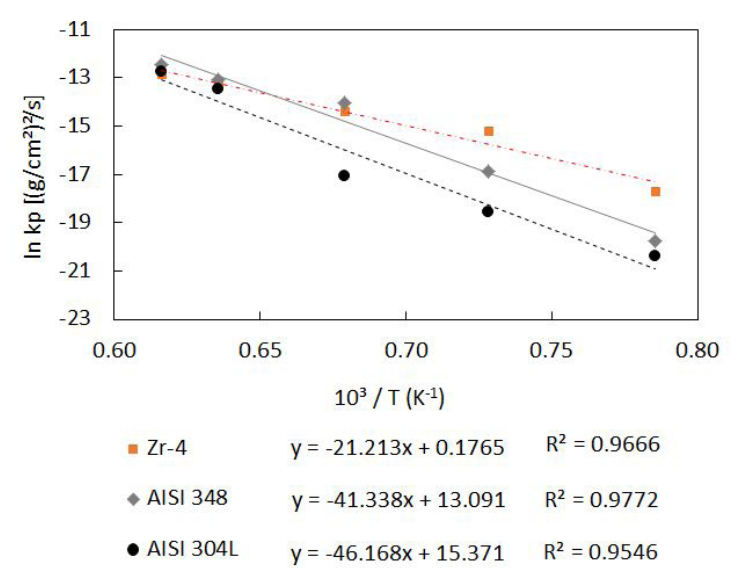

Figure 4. Arrhenius plot of the parabolic oxidation constants of AISI 304L, AISI 348, and Zircaloy-4 in water, where $\mathrm{R}^{2}$ is the coefficient of determination of each linear regression.

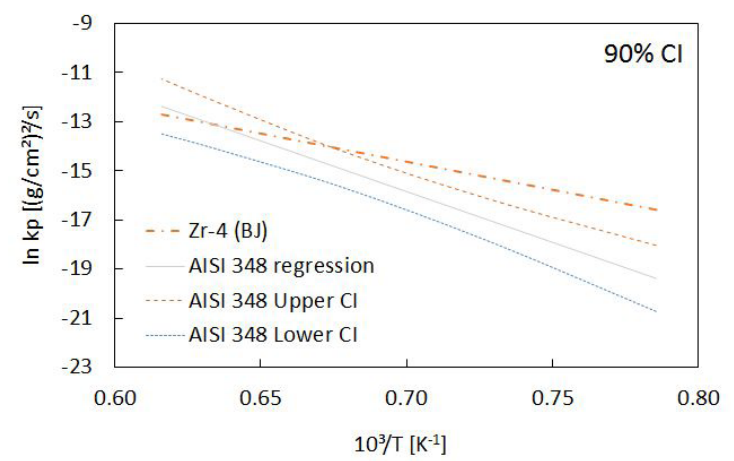

Figure 5. Arrhenius plot of AISI 348 proposed model and its $90 \%$ Confidence Intervals (CI) comparing to $\mathrm{BJ}^{20}$ model for Zircaloy metal-water reaction.

and compares the results against $\mathrm{BJ}^{20}$ model for Zircaloy metal-water reaction. The results clearly show that due to its higher activation energy, AISI 348 oxidation rate beyond $1200^{\circ} \mathrm{C}$ can surpass zirconium based alloys ${ }^{10,11}$.

\subsection{Characterization}

After oxidation, samples were cooled down to room temperature and photographed. Figures 6, 7, and 8 show, respectively, the samples of AISI 304L, AISI 348, and 


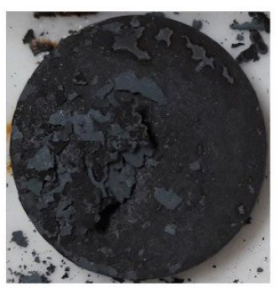

(a)

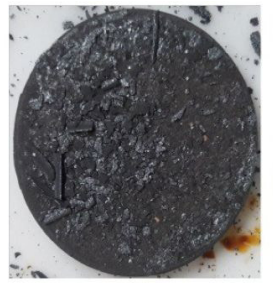

(b)

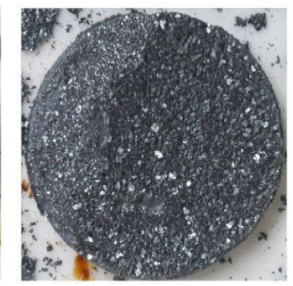

(c)

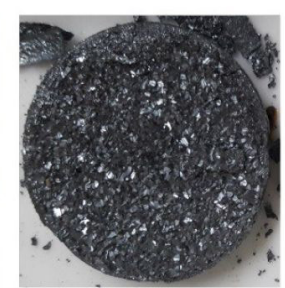

(d)

Figure 6. Photos of AISI 304L samples surfaces after $1.5 \mathrm{~h}$ of oxidation in water at (a) $1100{ }^{\circ} \mathrm{C}$, (b) $1200{ }^{\circ} \mathrm{C}$, (c) $1300{ }^{\circ} \mathrm{C}$, and (d) $1350{ }^{\circ} \mathrm{C}$.

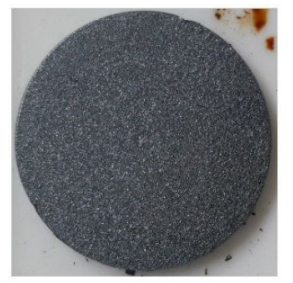

(a)

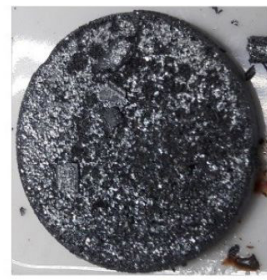

(b)

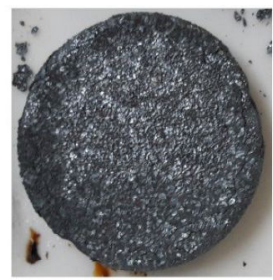

(c)

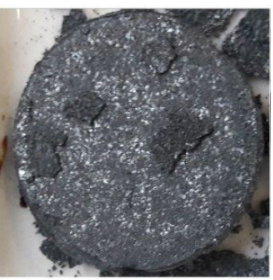

(d)

Figure 7. Photos of AISI 348 samples surfaces after $1.5 \mathrm{~h}$ of oxidation in water at (a) $1100{ }^{\circ} \mathrm{C}$, (b) $1200^{\circ} \mathrm{C}$, (c) $1300{ }^{\circ} \mathrm{C}$, and (d) $1350{ }^{\circ} \mathrm{C}$.

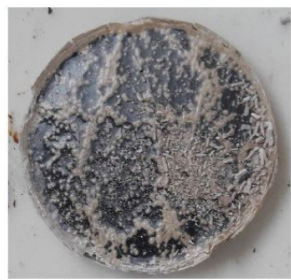

(a)

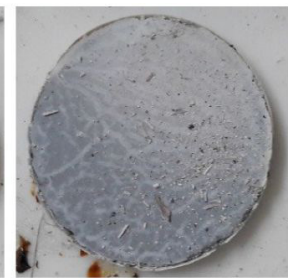

(b)

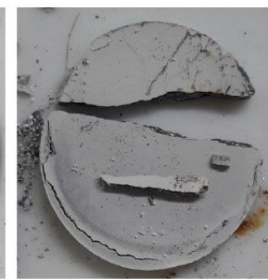

(c)

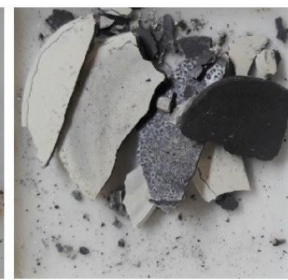

(d)

Figure 8. Photos of Zircaloy-4 samples surfaces after $1.5 \mathrm{~h}$ of oxidation in water at (a) $1100^{\circ} \mathrm{C}$, (b) $1200{ }^{\circ} \mathrm{C}$, (c) $1300{ }^{\circ} \mathrm{C}$, and (d) $1350{ }^{\circ} \mathrm{C}$.

Zircaloy-4 after $1.5 \mathrm{~h}$ of oxidation in water at four different temperatures. Despite presenting the highest oxidation resistance at $1100^{\circ} \mathrm{C}$, AISI 304L also showed scale spallation. The spallation debris are highly undesirable as they might accumulate inside the reactor core and block water flow channels during the reflood phase. On the other hand, at $1350{ }^{\circ} \mathrm{C}$, Zircaloy samples broke off during their removal from crucible, indicating embrittlement. Thus, at the temperature that stainless steel would start to melt $\left(1400^{\circ} \mathrm{C}\right)$, Zircaloy might start to lose its integrity.

Cross-section SEM image of AISI 304L oxidized in water at $1300{ }^{\circ} \mathrm{C}$ is shown in Figure 9. It shows multilayer oxide scales with voids, containing chromia, spinel, iron and nickel oxides. The innermost spinel thick layer, which is separated from the external magnetite layer by voids, shows excellent contact at the scale/metal interface. On the other hand, the magnetite layer, identified by Raman spectroscopy, might break off due to scale spallation.

The $\mathrm{Cr}$ content plays an important role on the oxidation resistance of stainless steels. The diffusion of $\mathrm{Cr}$ from the steel bulk to the oxide scale is temperature dependent. Fine grain size improves oxidation resistance by increasing the supply of $\mathrm{Cr}$ to the surface ${ }^{24,25}$. The ability of an alloy to endure $\mathrm{Cr}$ vaporization without losing the protective properties of the oxide is expected to be dependent on the rate of supply of $\mathrm{Cr}$ from the alloy to the oxide scale. Austenitic steels, such as 304 and 348 can experience accelerated $\mathrm{Cr}$ loss and oxidation rates due to the formation of a volatile oxy-hydroxide, $\mathrm{CrO}_{2}(\mathrm{OH})_{2}$. Although both AISI 304L and 348 contains $\sim 18 \% \mathrm{Cr}$, these alloys are unable to form a protective $\mathrm{Cr}$-rich oxide in water at these temperatures. EDS maps for $\mathrm{Fe}, \mathrm{Cr}$, and Ni may be visualized in Figures 10 and 11 for AISI 348 samples exposed in steam at $1100{ }^{\circ} \mathrm{C}$ and at $1300{ }^{\circ} \mathrm{C}$, respectively. Both show that neither $\mathrm{Cr}$ nor $\mathrm{Ni}$ were observed in the external layer ${ }^{26}$. Thus, oxidation kinetics reflects the rapid reaction of iron oxides formation rates ${ }^{3,27}$. This fact is also in accordance with other studies ${ }^{15,26,28}$.

Nevertheless, AISI 304L showed higher activation energy and also better oxidation resistance comparing to AISI 348, due to its higher $\mathrm{Cr}$ content ${ }^{2,19,29}$. After the exposures, AISI 304L non-reacting nucleus still presented a slightly higher $\mathrm{Cr}$ content comparing to AISI 348 samples.

SEM was also used to investigate the surface morphology with subsequent chemical analysis by EDS to identify alloying elements (up to a given depth) in the outermost layer. The results showed that the outward grown magnetite had lower density of grain boundaries (large grain size) ${ }^{29}$ and higher $\mathrm{Cr}$ depletion in the more oxidized samples. 


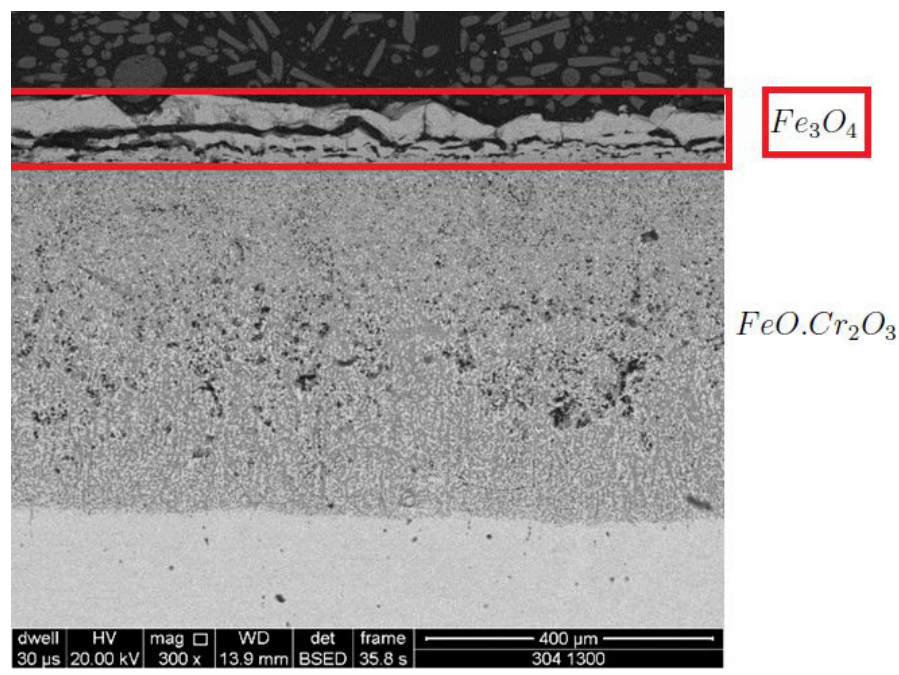

Figure 9. Cross-section SEM image of AISI 304L layers after $1.5 \mathrm{~h}$ at $1300^{\circ} \mathrm{C}$ oxidation. The outer magnetite layer is highlighted in red.

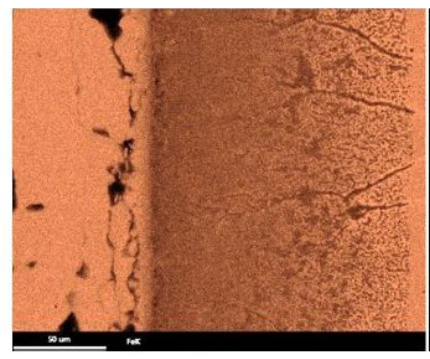

(a)

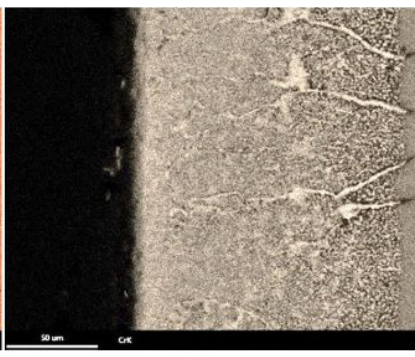

(b)

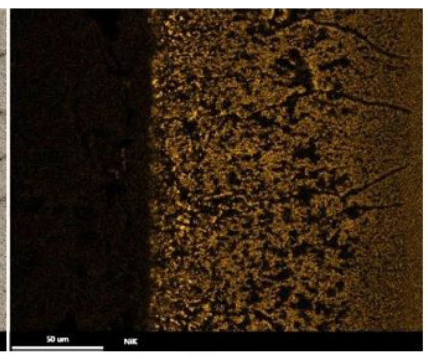

(c)

Figure 10. EDS maps of AISI 348 sample after $1 \mathrm{~h}$ oxidation at $1100{ }^{\circ} \mathrm{C}$ showing (a) $\mathrm{Fe}$, (b) $\mathrm{Cr}$, and (c) Ni profiles. The outer layer is on the left $\operatorname{side}^{26}$.

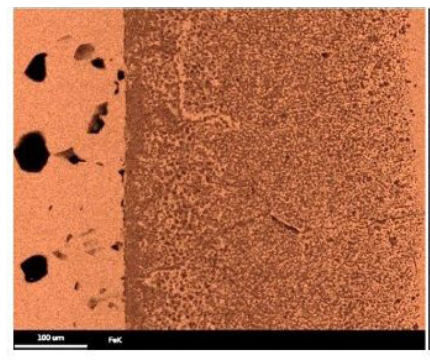

(a)

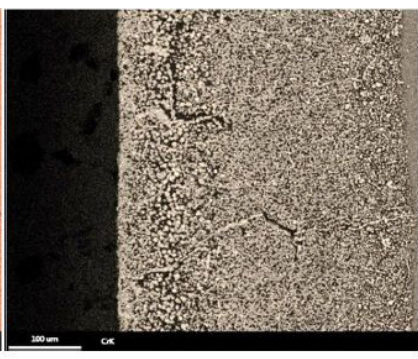

(b)

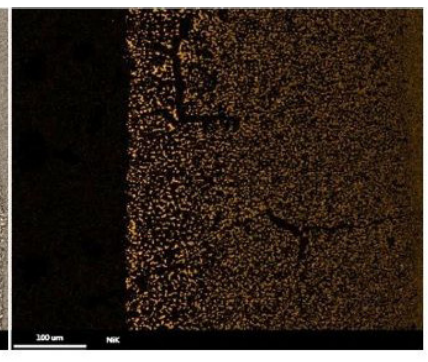

(c)

Figure 11. EDS maps of AISI 348 sample after 5 min oxidation at $1300{ }^{\circ} \mathrm{C}$ showing (a) $\mathrm{Fe}$, (b) $\mathrm{Cr}$, and (c) Ni profiles. The outer layer is on the left side ${ }^{26}$.

For example, due to the higher oxidation resistance of AISI 304L up to $1200{ }^{\circ} \mathrm{C}$, it was possible to identify other alloying elements than $\mathrm{Fe}$ in surface of a sample oxidized at $1200^{\circ} \mathrm{C}$. However, at $1300^{\circ} \mathrm{C}$ and beyond, a very thick $\mathrm{Fe}$ (II,III) oxide rich layer did not allow $\mathrm{Cr}$ and Ni identification.

\subsection{Hydrogen generation}

Although the experimental apparatus did not measured hydrogen generation, it is possible to derive hydrogen generation curves using weight gain results ${ }^{10,26}$, by considering the relation given by Equation 3 .

$\left(\frac{\mathrm{H}_{2}}{\mathrm{~A}}\right)=2 \frac{\mathrm{M}_{\mathrm{H}_{2}}}{\mathrm{M}_{\mathrm{O}_{2}}}\left(\frac{\Delta \mathrm{w}}{\mathrm{A}}\right)$

Where $\mathrm{H}_{2} / \mathrm{A}$ and $\Delta \mathrm{w} / \mathrm{A}$ are in the same unit; $\mathrm{M}_{\mathrm{H} 2}$ and $\mathrm{M}_{\mathrm{O} 2}$ are the molecular weights of hydrogen and oxygen, respectively; and 2 is the number of hydrogen moles produced for each mole of oxygen reacted. 
Figure 12 presents the hydrogen generation curves of AISI 348, comparing the experimental results and the predictions given by the mixed linear-parabolic model. Figure 13 shows that the upper interval with a $90 \%$ confidence level of the parabolic model is sufficient for a conservative prediction of hydrogen generation from AISI 348 by metal-water reaction in severe accidents. As the experiments did not measure hydrogen generation and there might be loss of mass (part of the non-adherent oxide layer), it is reasonable that the model presents significant uncertainty. Nonetheless, other authors reported similar level of uncertainty in the activation energy ${ }^{15,16}$ and the prediction model for AISI 348 hydrogen generation is in agreement with the experimental results obtained by other laboratories ${ }^{30}$.

AISI 348 proposed model upper confidence interval seems like Brassfield et al. ${ }^{15}$ correlation. This fact is in accordance to Pint et al. ${ }^{2}$, where typical 18-8 stainless steels (e.g., 304L, $321 \mathrm{~L}, 347$ ) all performed similarly in TGA experiments.

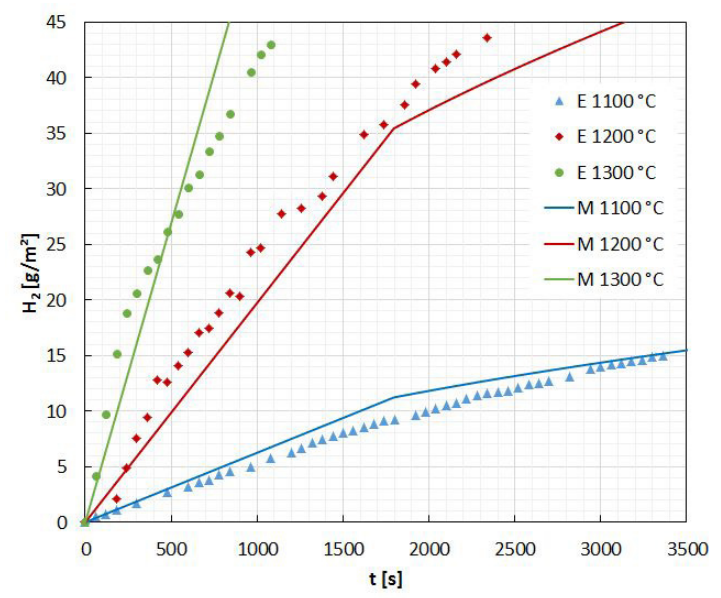

Figure 12. Evolution of the hydrogen generation curves for AISI 348 at $1100^{\circ} \mathrm{C}, 1200^{\circ} \mathrm{C}, 1300^{\circ} \mathrm{C}$ in water, comparing typical experimental results $(\mathrm{E})$ with the linear parabolic model $(\mathrm{M})$.

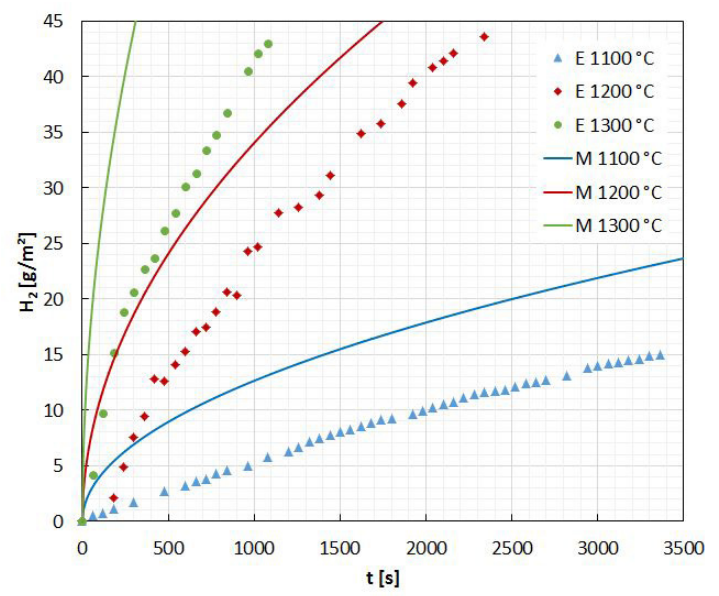

Figure 13. Evolution of the hydrogen generation curves for AISI 348 at $1100{ }^{\circ} \mathrm{C}, 1200^{\circ} \mathrm{C}, 1300^{\circ} \mathrm{C}$ in water, comparing typical experimental results (E) with the upper confidence interval model (M), considering that confidence level is $90 \%$.
In $\mathrm{SA}$ conditions, where cladding temperature can be higher than $1200{ }^{\circ} \mathrm{C}$, stainless steel cladding might lead to a faster hydrogen production comparing to Zircaloy. Even thought, it presents a better performance at lower temperatures. Thus, it can be considered a better option regarding hydrogen generation only in Design Basis Accidents (DBA) ${ }^{11}$.

\section{Conclusions}

Oxidation of AISI 304L and 348 in water was studied at $1000-1350{ }^{\circ} \mathrm{C}$ in terms of kinetics and scale composition. Based on obtained results, the following conclusions can be made:

1. Oxidation of both alloys followed mixed linear-parabolic rate kinetics. Multilayer scales with voids, consisting mainly of Fe (II,III) oxide and $\mathrm{Fe}-\mathrm{Cr}$ spinels were observed.

2. From the obtained data, a kinetic model is proposed to predict the oxidation of AISI 348. It presented lower activation energy and lower oxidation resistance comparing to AISI 304L.

3. For design basis LOCA, stainless steel clad presents lower hydrogen generation comparing to Zircaloy.

4. For an accident of the severity of Fukushima, stainless steel clad offers no significant advantage over Zircaloy concerning hydrogen generation.

\section{Acknowledgements}

The authors are grateful for the support from CAPES and CNPq, for César Yuji Narita on TGA and for Lea Sarita Montagna on SEM analysis.

\section{References}

1. Terrani KA. Accident tolerant fuel cladding development: promise, status, and challenges. J Nucl Mater. 2018;501:13-30. http://dx.doi.org/10.1016/j.jnucmat.2017.12.043.

2. Pint BA, Terrani KA, Brady MP, Cheng T, Keiser JR. High temperature oxidation of fuel cladding candidate materials in steam-hydrogen environments. J Nucl Mater. 2013;440(1-3):420-7. http://dx.doi.org/10.1016/j.jnucmat.2013.05.047.

3. Terrani KA, Zinkle SJ, Snead LL. Advanced oxidationresistant iron-based alloys for LWR fuel cladding. J Nucl Mater. 2014;448(1-3):420-35. http://dx.doi.org/10.1016/j. jnucmat.2013.06.041.

4. Ganguly C, Roy PR. A comparative study of zircaloy and stainless steel as cladding material for pressurised water reactor. Bombay, India: Bhabha Atomic Research Centre; 1977.

5. Abe A, Giovedi C, Gomes DS. Revisiting stainless steel as PWR fuel rod cladding after Fukushima Daiichi accident. Journal of Energy and Power. 2014;8:973-80. http://dx.doi. org/10.17265/1934-8975/2014.06.001.

6. Knief RA. Nuclear engineering. theory and technology of commercial nuclear power. 2nd ed. Washington: Hemisphere Publishing Corporation; 1992.

7. Massey CP, Terrani KA, Dryepondt SN, Pint BA. Cladding burst behavior of Fe-based al loys under LOCA. J Nucl Mater. 2016;470:128-38. http://dx.doi.org/10.1016/j.jnucmat.2015.12.018.

8. Powers DA, Meyer RO. NUREG-0630: cladding swelling and rupture models for LOCA analysis. Washington: NRC; 1980.

9. U.S. Nuclear Regulatory Commission. Standard review plan analysis reports for nuclear power plants plants: LWR edition (NUREG-0800) section 4.2 fuel system design rev. 3. Washington; 
2007 [cited 2019 Sep 25]. Available from: https://www.nrc.gov/ readingrm/doc-collections/nuregs/staff/sr0800/

10. Camp AL, Cummings JC, Sherman MP, Kupiec CF, Healy RJ, Caplan JS, et al. Light water reactor hydrogen manual. Albuquerque: Sandia National Laboratories; 1983. (Report No.: NUREG/CR-2726).

11. Strasser A, Santucci J, Lindquist K, Yario W, Stern G, Goldstein $\mathrm{L}$, et al. Evaluation of stainless steel cladding for use in current design LWRs final report. 1982. (Report No.: EPRI-NP-2642).

12. Huntz AM, Reckmann A, Haut C, Sévérac C, Herbst M, Resende FCT, et al. Oxidation of AISI 304 and AISI 439 stainless steels. Mater Sci Eng A. 2007;447(1-2):266-76. http://dx.doi. org/10.1016/j.msea.2006.10.022.

13. Sabioni ACS, Huntz AM, Luz EC, Mantel M, Haut C. Comparative study of high temperature oxidation behaviour in AISI 304 and AISI 439 stainless steels. Mater Res. 2003;6(2):179-85. http:// dx.doi.org/10.1590/S1516-14392003000200012.

14. Carvalho CER, Costa GM, Cota AB, Rossi EH. High temperature oxidation behavior of AISI 304 and AISI 430 stainless steels. Mater Res. 2006;9(4):393-7. http://dx.doi.org/10.1590/S151614392006000400009.

15. Brassfield HC, White JF, Sjodahl L, Bittel JT. Recommended property and reaction kinetics data for use in evaluating a light-water-cooled reactor loss of coolant incident involving Zircaloy-4 or 304SS Clad UO2, GEMP-482. Cincinnati: General Electric Co.; 1968. (Report No.: GEMP-482).

16. Ishida T, Harayama Y, Yaguchi S. Oxidation of 304 stainless steel in high temperature. J Nucl Mater. 1986;140(1):74-84. http://dx.doi.org/10.1016/0022-3115(86)90198-4.

17. Electric Power Research Institute - EPRI. Severe accident management guidance technical basis report - volume 2: the physics of accident progression. Palo Alto: EPRI; 2012. (Report No.: 1025295).

18. Young DJ. High temperature oxidation and corrosion of metals. Sydney: Elsevier; 2016.

19. Croll JE, Wallwork GR. The high-temperature oxidation of iron-chromium-nickel alloys containing $0-30 \%$ chromium. Oxid Met. 1972;4(3):121-40. http://dx.doi.org/10.1007/BF00613088.

20. Baker LJ, Just LC. Studies of metal-water reactions at high temperatures experimental-and theoretical studies of the zirconium-water reaction. AEC Research and Development Report. Argonne: Argonne National Laboratory; 1962. (Report No.: ANL-6548). http://dx.doi.org/10.2172/4781681.

21. Billone MC, Chung HM, Yan Y. Steam oxidation kinetics of zirconium. Argonne: Argonne National Laboratory; 2002.

22. Urbanic VF, Heidrick TR. High-temperature oxidation of Zircaloy-2 and Zircaloy-4 in steam. J Nucl Mater. 1978;75(2):25161. http://dx.doi.org/10.1016/0022-3115(78)90006-5.

23. Cathcart JV, Pawel RE, McKee RA, Druschel RE, Yurek GJ, Campbell JJ, et al. Zirconium metal-water oxidation kinetics, IV: reaction rate studies. Oak Ridge: Oak Ridge National Laboratory; 1977. (Report No.: ORNL/NUREG-17).

24. Liang Z, Zhao Q. Steam oxidation of austenitic heat-resistant steels TP347H and TP347HFG at $650-800{ }^{\circ} \mathrm{C}$. Materials. 2019;12(4):577. http://dx.doi.org/10.3390/ma12040577.

25. Wright IG, Dooley RB. A review of the oxidation behaviour of structural alloys in steam. Int Mater Rev. 2010;55(3):129-67. http://dx.doi.org/10.1179/095066010X12646898728165.

26. Ševecek M, Krejcí J, Chalupová A, Kabátová J, Manoch F, Kocí J. Round robin exercise of the candidate ATF cladding materials within the IAEA ACTOF project. In: American Nuclear Society - ANS. Global/Top Fuel 2019. Seattle: ANS; 2019. p. 283-90.

27. Yuan J, Wang W, Zhu S, Wang F. Comparison between the oxidation of iron in oxygen and in steam at $650-750{ }^{\circ} \mathrm{C}$. Corros Sci. 2013;75:309-17. http://dx.doi.org/10.1016/j. corsci.2013.06.014.

28. Saunders SRJ, Monteiro M, Rizzo F. The oxidation behaviour of metals and alloys at high temperatures in atmospheres containing water vapour: a review. Prog Mater Sci. 2008;53(5):775-837. http://dx.doi.org/10.1016/j.pmatsci.2007.11.001.

29. Jonsson T. Microscopy of high temperature oxidation of iron and some stainless steels [thesis]. Göteborg: Department of Applied Physics, Chalmers University of Technology; 2007.

30. International Atomic Energy Agency - IAEA. Analysis of options and experimental examination of fuels for water cooled reactors with increased accident tolerance (ACTOF): final report of a coordinated research project. Vienna: IAEA; 2020. (Report No.: IAEA-TECDOC-1921). 